\title{
PREDICTION OF INSTITUTIONAL SECTOR DEVELOPMENT AND ANALYSIS OF ENTERPRISES ACTIVE IN AGRICULTURE
}

\author{
Vojtěch Stehel, Jakub Horák, Marek Vochozka
}

\section{Introduction}

Owing to a special role of agriculture in the national economy, governments have become the main suppliers as well as the main users of agricultural predictions (forecasts). They require internal forecasts to implement policies that provide technical and market support to the agricultural sector (Hedtrich, Loy, \& Mueller, 2012). Forecasts of agricultural production and prices ought to be helpful not only for the governments, but primarily for farmers and the entire agriculture industry. Thus, agriculture is an area where politicians, consumers, scientists and environmentalists encounter (Rivera-Ferre, 2008). Remeikiene, Rozsa, Gaspareniene and Pěnčík (2018) state that supportive political attitudes towards the agricultural sector along with employment of protectionist measures determine ignorance of the rules of supply and demand, distortion of the conditions of free market competition, closeness of the agricultural sector in comparison to other economic sectors, incomplete international agricultural price transmission, inconsistence of long-term market prices for agricultural commodities and existence of agriculture in disfavoured areas.

In its Europe 2020 development strategy, the European Commission has defined an ambitious goal of improving the level of resource efficiency ( $\mathrm{Li}, 2018)$. Analyses of technical efficiency and total factor productivity (TFP) within the Czech agriculture have been conducted by Čechura (2012). His objective consists in identifying key factors that determine an efficiency of input utilization and TFP development. He uses a fixed control model to estimate the technical efficiency and TFP design for the overall status in agriculture and its individual sectors. The results show that technical inefficiency is an important phenomenon of the Czech agriculture and its individual sectors. The most important factors that determine both the technical efficiency and the TFP are factors associated with institutional and economic changes, particularly a dramatic increase in meat imports and an increase in subsidies (Čechura, 2012). In addition, an analysis of agricultural productivity trends in the EU countries on the TFP basis was performed, for instance, by Dokic, Jovanovic and Vujanic (2017). Their results show that the overall EU agricultural productivity growth has slowed down in recent years and has lagged behind leading global competitors, which is mainly due to decreasing number of employees in agriculture. According to the authors, agriculture development should be established on scientific bases. Remeikiene et al. (2018) state that this may be caused when the volumes of the international trade in agricultural products are decreasing.

One of the basic principles of sustainable agriculture is therefore forecasting its future development. Forecasts are predominantly made using conventional econometric methods, with time series approaches having smaller roles (Klieštik, Vrbka, \& Rowland, 2018). In relation to certain dominance of agricultural economists, great emphasis has been put on explanations, yet the predictive power of models has been of only small concern. In recent years, several agricultural economists have been engaged in comparing forecasts with various other methods and their conclusions generally correspond to commonly accepted beliefs. In the case of short-term forecasting, combinations lead to better and more accurate prognoses, even better than the ones produced by vector auto-regression, which is surprisingly one of the best methods. For example, Klepáč and Hampel (2018) wanted to find out if it possible to predict bankruptcy 1-3 years ahead with the sound accuracy. Their results show 
that models are able to notice correct labels for active companies, however, the longer time period to bankruptcy is, the worse the results are, or the results are inconsistent for bankrupted companies which have been active till now. The authors of course also say that bankruptcy prediction is characterized by the fact that the results are markedly influenced by the data used and partly by setting of classification models. Karas and Režňáková (2017) verified whether bankruptcy predictors are specific in terms of industry or time and established which predictors can signal an imminent bankruptcy more than one period before bankruptcy occurs. The research confirmed their presumption. Authors identified indicators, which are industry-specific and are frequently associated with a specific period of time preceding the bankruptcy (for manufacturing companies: the return on assets and the net working capital to total assets; for construction companies: the net working capital to sales and the interest coverage). Karas and Režňáková (2017) identified also indicators whose inclusion in the model would probably increase its prediction capacity - these are the indicators return on assets, inventory turnover and asset composition. As demonstrated by Hedtrich, Loy and Mueller (2012), it is also surprising that econometric models as well as one-dimensional methods are poorly comparable and naive models. However, it is increasingly challenging to predict bankruptcy risk as corporations have become more global and more complex and as they have developed sophisticated schemes to hide their actual situations under the guise of optimization for tax authorities (Klieštik et al., 2018).

The price volatility of commodities has increased greatly in recent years. Information about the development of agricultural markets has disseminated among market participants to differing degrees. This information asymmetry is the basis for trading profits on markets. Different forecasting tools, particularly statistical and econometric methods, were developed in the agricultural sector in the past, but they did not achieve very good forecasting accuracy, thereby resulting in a considerable price risk. The additional information held by market participants and other people in the agricultural sector has been neglected by these tools (Hedtrich, Loy, \& Mueller, 2012).

Hedtrich et al. (2012) further add that methods using the "wisdom of crowds" effect achieved better or equal forecasting accuracy in many forecasting applications than the standard approaches applied. The "wisdom of crowds" effect indicates that groups reach better results than individuals or experts. Prediction markets are seen by the same authors, i.e. Hedtrich et al. (2012), as a new forecasting method. They use a trading mechanism similar to a stock market to achieve the "wisdom of crowds". Prediction markets are forums for trading contracts that yield payments based on the outcome of uncertain events. There is mounting evidence that such markets can help to produce forecasts of event outcomes with a lower prediction error than conventional forecasting methods (Valášková, Klieštik, Švábová, \& Adamko, 2018). For example, prediction market prices can be used to increase the accuracy of pollbased forecasts of election outcomes (Arrow et al., 2008).

Business analysis is used for collecting necessary data and their identification, including formulating the need for change(s) in functioning of organizations and facilitating the change(s). In terms of efficient use of business analyses, an infinite amount of data may be provided (Vochozka, Rowland, \& Vrbka, 2016). Andekina and Rakhmetova (2013) describes business analysis as a disciplined approach to implementing and managing changes within organizations, whether they are beneficial businesses, governments or non-profit organizations.

At present, artificial intelligence can be definitely recognized as a useful tool for business analyses and forecasting. This research may be dated back to the 1940s, and over the last three decades, it has been extended up to the point of solving agricultural problems as well (Rowland, \& Vrbka, 2016). Artificial neural networks are flexible in their own use, and are able to analyse highly complex patterns very quickly (Santin, 2008). These networks can be used to classify, approximate functions, and predominantly to predict time series (Altun, Bilgil, \& Fidan, 2007). Even in the agricultural sector, artificial intelligence has helped to develop machine learning algorithms from artificial neurons and artificial neural networks that mimic the human brain with synthetic neurons (Vochozka, 2017). The disadvantage of these networks is the need for large sample data, since many test observations are needed to produce such data, however this is very 
complicated for users (Hossain, Chao, Ismail, Noroozi, \& Khoo, 2017).

For data processing and business analyses, the so-called Kohonen network can be applied. It consists of an input layer that is completely interconnected with an output layer and is selforganizing, i.e. has the ability to learn without "a teacher". This network has a very wide range of uses, since it is an alternative network applicable to most neural network calculations (Vochozka \& Machová, 2018). It is used mainly for audio editing, speech processing, photos, videos, security applications, and allows for the projection of high dimensional data into lower dimension data (Konečný \& Trenz, 2010). When using this attractive model to group data sets into different groups, the data are grouped by a system where records within a group tend to be similar to each other and records in different groups are different. Many experimental results show that Kohonen networks are very effective not only for assessing agricultural companies (Han \& Wang, 2008).

The objective of the contribution is an analysis of companies active in agriculture of the Czech Republic using Kohonen network and the subsequent prediction of their development.

\section{Data and Methods}

The research question was set: Is it possible to find out the status of companies operating in agriculture in the Czech Republic on the basis of cluster analysis using artificial intelligence?

For the purposes of this contribution, a data set will be created, which will include complete data from financial statements of 4,201 companies active in agriculture of the Czech Republic in 2016. These are the entities whose core activities are classified in Section A of the economic activities classification CZ-NACE. The set of companies will be generated from the Bisnode Albertina database.

The data will be listed in an Excel table. Each line will contain data from financial statement of one concrete company, which will be identified by its name and identification number. The data set will not contain the data of the enterprises that did not perform their core activities in the entire monitored period, that is the companies that were closed in this period (and therefor did not have any significant influence on the direction of national economy), and companies that started their activities (and did not have a significant influence on the direction of the agriculture sector in the $\mathrm{CR}$ either). The companies that started their activities on 1 January 2016 or those that finished their business on 31 December 2016 could have been considered; however, this would not have big influence on achieving the objective of the contribution.

Moreover, the columns of data showing no variance were also excluded.

The data set will be subsequently subjected to cluster analysis using Kohonen network. For cluster analysis, Dell's Statistica software, version 12 will be used. There will be used the Data mining module and as a specific tool, neural networks. Neural network without a teacher (Kohonen network) will be used. The data for analysis will be chosen - Excel table with data set. In all cases these are continuous predictors. The set will be divided into three parts:

1. Training data set: represents $70 \%$ of the enterprises from the data set. For this set, Kohonen network will be created.

2. Testing data set: it includes $15 \%$ of companies from the original data set. This set will be used for verifying the parameters of created Kohonen network.

3. Validation data set: this set will also contain $15 \%$ of the companies from the data set. This data set will be tested the applicability or inapplicability of the created Kohonen network.

Topological length and width of Kohonen network will be set at 10 . The number of iterations will be set at 10,000. However, it shall be noted that error level is a decisive factor. If the Kohonen network parameters are not improved with each reiteration, the training will be finished before the 10,000 th iteration is completed. In case that the network parameters do not improve with the 10,000th reiterations, the entire process must be repeated, and a higher number of required iterations shall be set in order to get the best result possible. The learning speed will be set at 0.1 at the beginning and 0.02 at the end.

The results, i.e. the division of the individual companies into 100 clusters will be entered in Excel table. Subsequently, the individual clusters will be subjected to analysis of absolute and selected indicators (or more precisely, their mean values - arithmetic average) and the results will be interpreted. 


\section{Fig. 1: Number of companies in each cluster of Kohonen network}

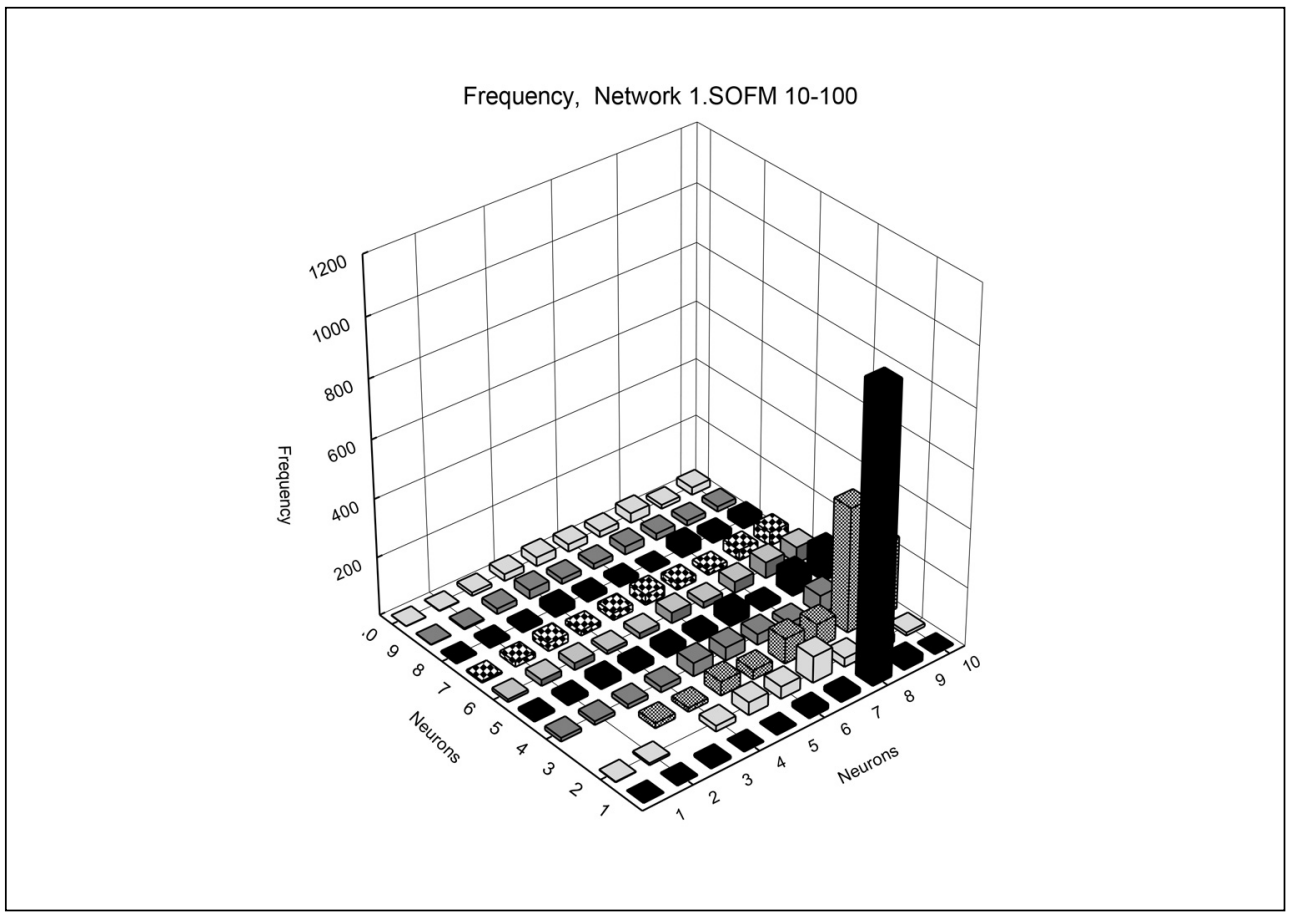

Source: own

\section{Results}

Based on the methods applied, clusters were created. The number of companies in each cluster of the Kohonen network is shown in Fig. 1.

Fig. 1 shows a 3-D representation of the Kohonen network created and the number of companies in the individual clusters. The figure shows that the highest representation of companies is in cluster $(1,8)$, and cluster $(3,9)$. The third place is occupied by cluster $(3,10)$. Moreover, the cluster with a higher representation of companies are clusters $(4,10)$ and $(5,10)$. For the remaining clusters, the representation of companies is significantly lower. It shall also be noted that three of the Kohonen network clusters are not occupied. More particularly, these are clusters $(2,3),(3,1)$ and $(3,2)$.

To get a detailed view on representation of companies in the individual clusters, Fig. 1 is complemented by concrete values shown in Tab. 1.
Tab. 1 shows that only the clusters marked in grey include more than 100 companies. Other clusters include less than 100 companies, with on $(2,7)$ cluster includes 90 companies. The following analysis deals only with the highlighted clusters. They contain data on 1,919 companies, which accounts for $45 \%$ of all the companies in the set, although they are in 5 clusters out of the 100 existing (and 97 occupied ones). Moreover, one of the clusters, specifically $(1,8)$, includes 990 companies, i.e. almost $24 \%$ of the companies in the set. It can therefore be assumed, that the analysis performed will have a sufficient explanatory power and will be able to represent the potential of the entire Czech agriculture. The mean values of the set as a whole, and selected clusters are given in Tab. 2 .

Tab. 2 clearly shows the difference of values for agriculture as a whole and for individual clusters. The mean values for the whole agriculture sector are significantly higher 


\section{Tab. 1: Number of companies in individual clusters of Kohonen network}

\begin{tabular}{c|r|r|r|r|r|r|r|r|r|r} 
Neuron & $\mathbf{1}$ & $\mathbf{2}$ & $\mathbf{3}$ & $\mathbf{4}$ & $\mathbf{5}$ & $\mathbf{6}$ & $\mathbf{7}$ & $\mathbf{8}$ & $\mathbf{9}$ & $\mathbf{1 0}$ \\
\hline 1 & 1 & 3 & 9 & 2 & 4 & 17 & 16 & 990 & 26 & 4 \\
\hline 2 & 2 & 7 & 0 & 20 & 44 & 42 & 90 & 30 & 29 & 11 \\
\hline 3 & 0 & 0 & 18 & 14 & 48 & 32 & 86 & 82 & 427 & 249 \\
\hline 4 & 13 & 13 & 15 & 19 & 46 & 45 & 37 & 22 & 64 & 150 \\
\hline 5 & 9 & 14 & 26 & 22 & 27 & 22 & 47 & 15 & 72 & 103 \\
\hline 6 & 10 & 21 & 24 & 13 & 19 & 37 & 21 & 39 & 55 & 56 \\
\hline 7 & 6 & 17 & 28 & 17 & 25 & 36 & 23 & 17 & 37 & 48 \\
\hline 8 & 6 & 10 & 12 & 28 & 17 & 16 & 7 & 40 & 23 & 30 \\
\hline 9 & 2 & 5 & 19 & 31 & 18 & 19 & 28 & 23 & 18 & 18 \\
\hline 10 & 1 & 2 & 12 & 24 & 31 & 26 & 21 & 34 & 14 & 26 \\
\hline
\end{tabular}

\section{Tab. 2: Mean values for selected variables of most represented clusters}

\begin{tabular}{|c|c|c|c|c|c|c|}
\hline Item & In total & $(1,8)$ & $(3,9)$ & $(3,10)$ & $(4,10)$ & $(5,10)$ \\
\hline Total assets & $74,413.5$ & $1,297.1$ & $2,914.8$ & $5,281.9$ & $7,782.5$ & $13,113.9$ \\
\hline Fixed assets & $50,237.8$ & 694.7 & $1,164.8$ & $2,651.2$ & $4,589.1$ & $7,737.8$ \\
\hline Intangible fixed assets & 139.5 & 5.1 & 12.0 & 4.4 & 8.3 & 82.0 \\
\hline Tangible fixed assets & $46,922.1$ & 524.8 & $1,123.8$ & $2,340.4$ & $4,170.6$ & $6,410.0$ \\
\hline Land & $20,010.9$ & 57.3 & 56.9 & 189.6 & 468.8 & $1,010.0$ \\
\hline Constructions & $15,733.1$ & 110.5 & 171.5 & 285.6 & $1,182.2$ & $1,424.7$ \\
\hline $\begin{array}{l}\text { Separate movable things and sets } \\
\text { of movable things }\end{array}$ & $6,748.5$ & 53.2 & 201.0 & 366.4 & 693.5 & $1,112.6$ \\
\hline Long-term financial assets & $3,176.2$ & 164.8 & 29.0 & 306.7 & 410.2 & $1,245.8$ \\
\hline Current assets & $23,623.8$ & 589.0 & $1,705.8$ & $2,555.4$ & $3,035.1$ & $4,961.8$ \\
\hline Inventories & $9,576.0$ & 68.4 & 284.4 & 643.5 & 802.6 & $1,580.9$ \\
\hline Material & 954.6 & 6.7 & 23.4 & 38.5 & 66.5 & 41.1 \\
\hline Unfinished and semi-finished products & $1,985.7$ & 6.9 & 31.6 & 57.5 & 82.5 & 308.5 \\
\hline Long term receivables & 487.9 & 19.1 & 35.0 & 17.3 & 169.2 & 101.0 \\
\hline Short term receivables & $7,784.0$ & 182.1 & 661.8 & $1,130.4$ & $1,354.3$ & $2,221.3$ \\
\hline Trade receivables (short-term) & $4,260.9$ & 43.0 & 198.8 & 354.8 & 487.2 & 700.4 \\
\hline Stat - tax assets & 691.7 & 10.2 & 31.6 & 68.6 & 116.6 & 279.6 \\
\hline Other advances provided & 165.1 & 4.0 & 9.9 & 21.3 & 80.9 & 32.9 \\
\hline Short-term financial assets & $5,789.6$ & 320.6 & 724.7 & 764.8 & 712.3 & $1,058.6$ \\
\hline Cash & 141.8 & 49.4 & 54.8 & 109.0 & 94.4 & 185.1 \\
\hline Bank accounts & $4,466.3$ & 96.9 & 236.0 & 302.8 & 279.9 & 384.6 \\
\hline Accruals & 513.9 & 10.5 & 42.5 & 73.5 & 150.2 & 389.3 \\
\hline
\end{tabular}




\section{Fig. 2: Mean values of assets for agriculture and for selected clusters}

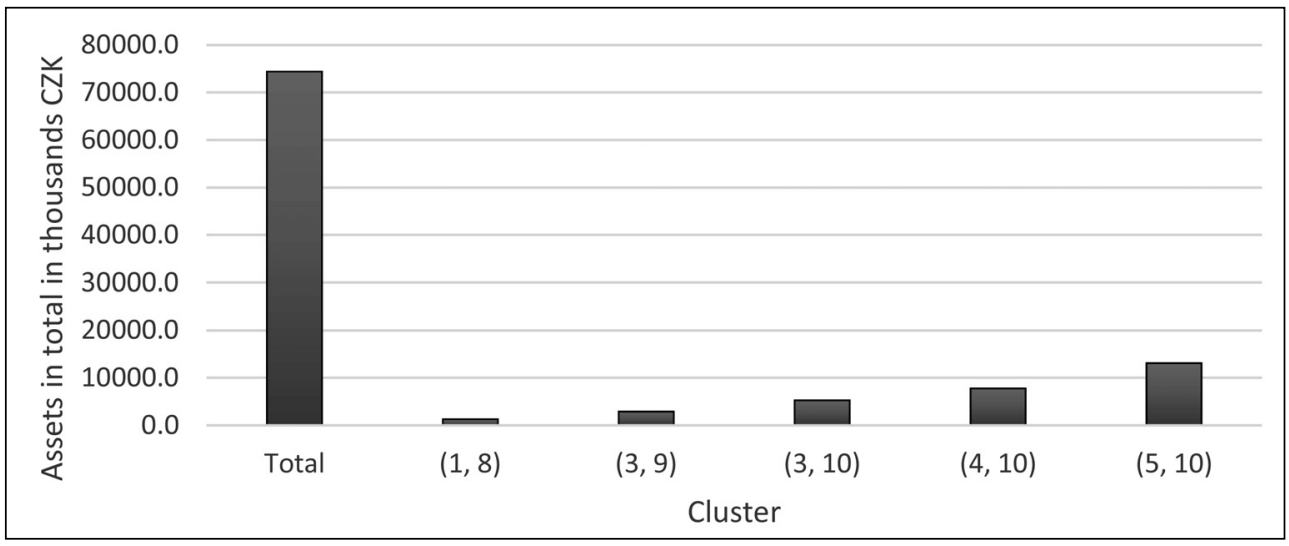

Source: own

\section{Fig. 3: Mean values of fixed assets for agriculture sector and for selected clusters}

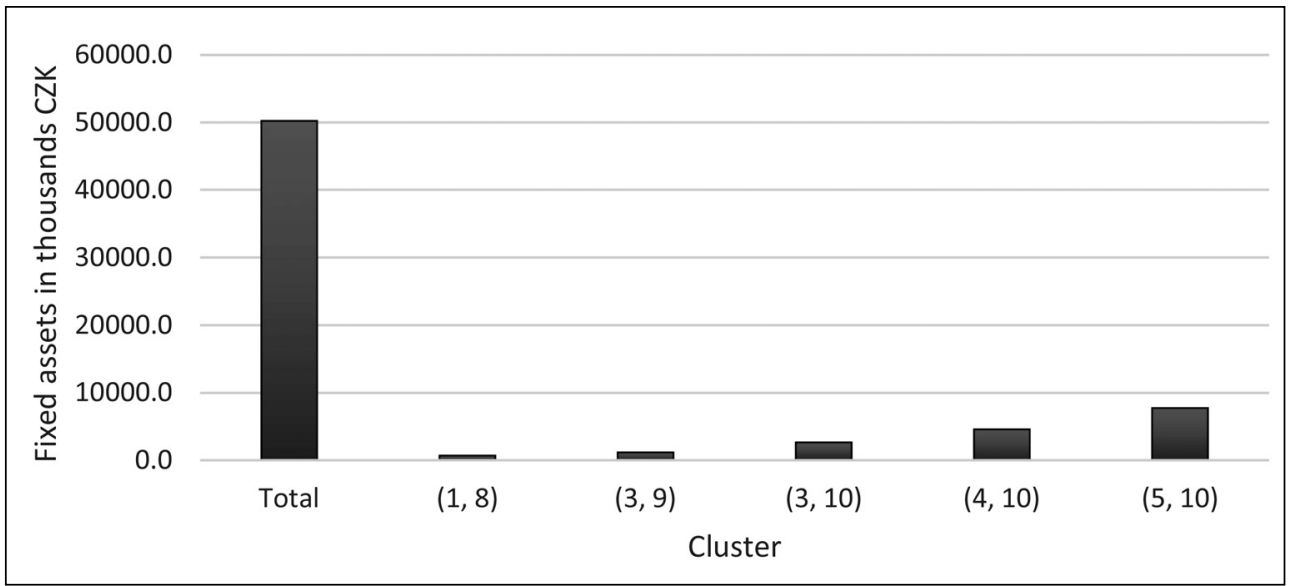

Source: own

than the mean values for the clusters with the highest number of companies. This could mean that the selected clusters considered also the size of companies as one of the parameters for clustering (this does not necessarily mean it was a decisive factor; it could have happened inadvertently). The most important values of assets are given in graphs below.

Fig. 2 compares the mean values of assets for agriculture in total and for individual clusters.
For the sector of agriculture, average balance sheet, that is, the value of assets is almost CZK 75 million per company. Cluster $(1,8)$ achieves the average assets value of CZK 1.2 million. Only one cluster, specifically $(5,10)$ achieves the average value of total assets of more than CZK 10 million. In this cluster with the value of more than CZK 13 million the companies have more than CZK 5 million at their disposal compared to the companies 


\section{Fig. 4: Mean values of current assets for agriculture and for selected clusters}

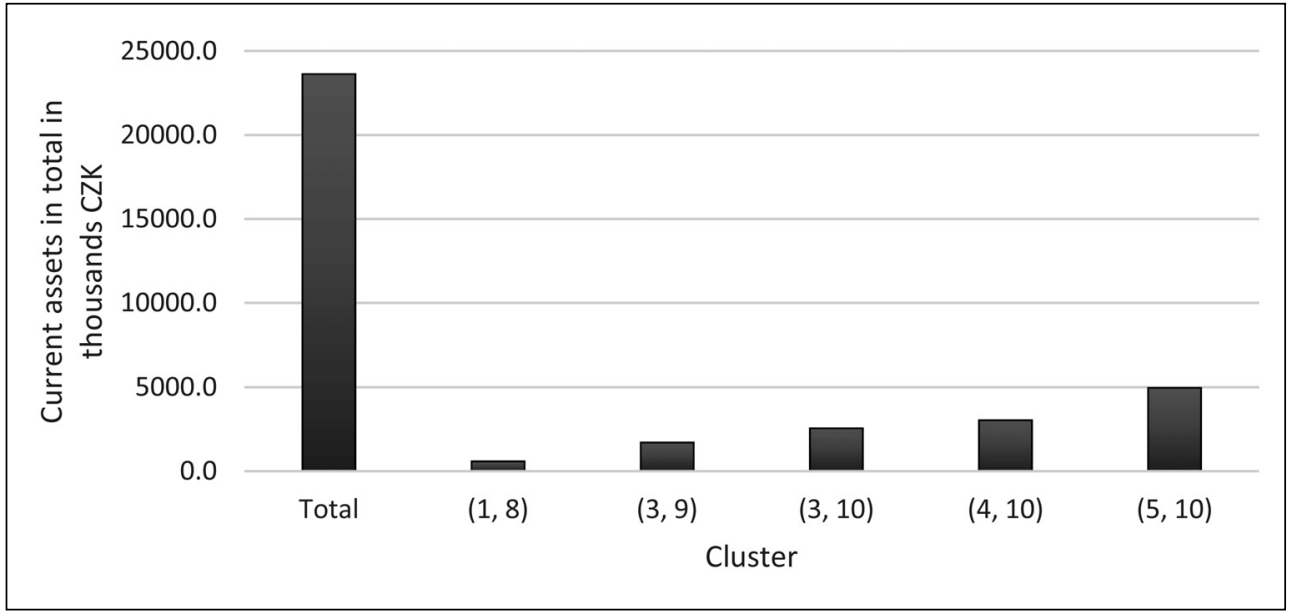

Source: own

in the second most successful cluster $(4,10)$. These are followed by clusters $(3,10)$ and $(3,9)$ with the assets at the amount of almost CZK 5.3 million, or almost CZK 3 million.

An indicator of equal importance, which differs the companies in the individual clusters is the amount of fixed assets (Fig. 3).

Agriculture is a very specific sector. It is a strategic institutional sector of the national economy. Its results are highly dependent on weather and external influencers. The outputs of agricultural production are seasonal in character. Due to this fact, irregular cash flows are typical for companies active in agriculture. In agriculture is also effort for higher level of production mechanization and automation. Fixed assets thus indicate a possible marginal rate of replacement of capital for work. The more machines the companies have, the fewer workers are needed. In agriculture, the amount of fixed assets per one company is above CZK 50 million. The companies in clusters examined use fixed assets significantly less. The best position has the cluster $(5,10)$, achieving the value of more than CZK 7.2 million. The cluster with the highest number of companies, cluster $(1,8)$, achieves the value of almost CZK 0.7 million per company. The second most represented cluster $(3,9)$ achieves the amount of CZK 1.16 million per company. The value of the two remaining clusters is CZK 2.6 million
$(3,10)$, or 4.5 million for cluster $(4,10)$. Assuming that using fixed assets is growing with the size of company, it may be concluded that the clusters examined do not include large or extremely large companies active in agriculture of the Czech Republic. Another variable examined is current assets. For more details, see Fig. 4.

Current assets (although not equal to working capital) are an important part of each company, in particular for an agricultural company. It includes inventories, receivables and financial assets. Small animals, feed and tools costs are relatively high in agriculture companies. Similarly, the payment culture in the Czech Republic is not optimal; therefore the level of receivables is rather high. The highest mean values of current assets are in agriculture as a whole (more than CZK 23.6 million). The companies in the cluster $(1,8)$ have the average current assets value of CZK 0.6 million. The value of current assets for cluster $(3,9)$ is less than CZK 2 million. The remaining three clusters $(3,10),(4,10)$ and $(5,10)$ include the companies with current assets mean values higher than CZK 2 million. Fig. 5 shows the amounts of cash in the context.

Fig. 5 shows that an average agricultural company has cash at the amount above CZK 141 thousand. All companies in the examined clusters have a relative higher amount of money. 


\section{Business Administration and Management}

\section{Fig. 5: Mean values of cash in agriculture and in selected clusters}

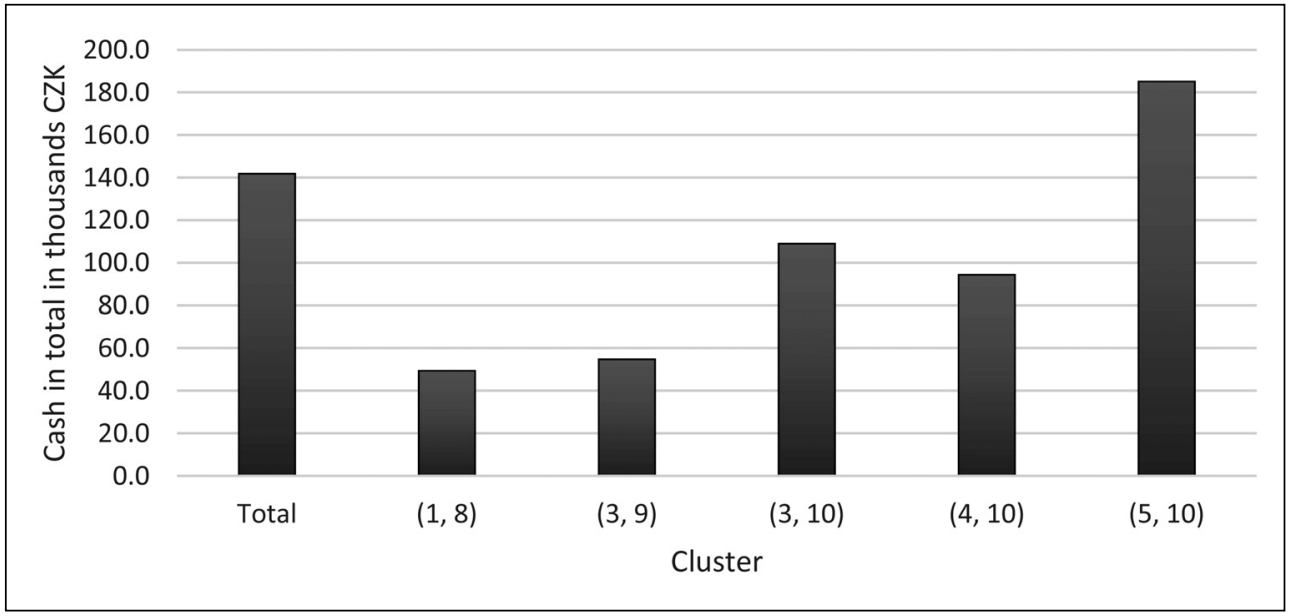

Source: own

In cluster $(5,10)$, the amount of cash is above the average (more than CZK 185 thousand).

Not surprisingly, equally interesting are the values of funding sources - capital. The selected liabilities items and comparison of their mean values are shown in Tab. 3 .
Attention should be also paid to the structure of financing agriculture companies. Therefore, Fig. 6 shows the mean values of equity and borrowed capital for each cluster and for agriculture.

Fig. 6 shows that in the agricultural sector, the share of borrowed capital is $33 \%$ on average. In

\section{Fig. 6: \\ Mean values of equity and borrowed capital for agriculture and for selected clusters}

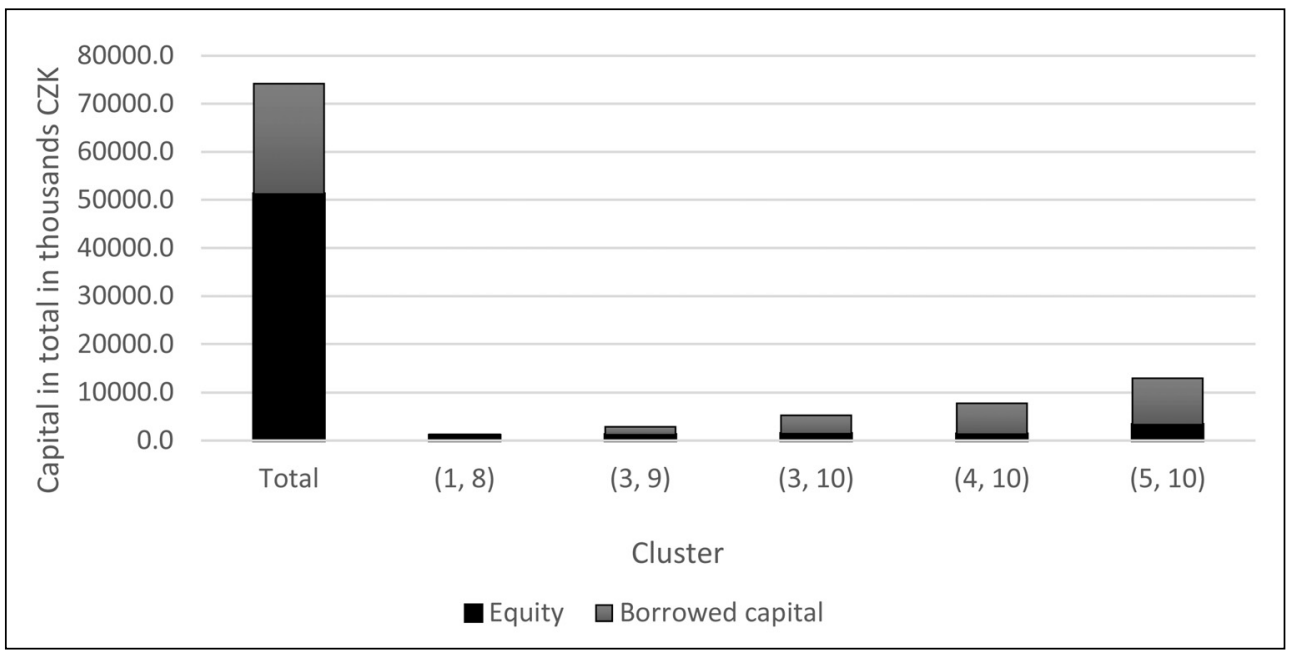


Tab. 3: Mean values of liabilities for set examined and selected clusters

\begin{tabular}{|c|c|c|c|c|c|c|}
\hline Item & In total & $(1,8)$ & $(3,9)$ & $(3,10)$ & $(4,10)$ & $(5,10)$ \\
\hline Total liabilities & $74,432.0$ & $1,297.2$ & $2,914.8$ & $5,281.9$ & $7,782.5$ & $13,113.9$ \\
\hline Equity & $51,225.2$ & $1,062.6$ & $1,213.0$ & $1,420.2$ & $1,334.9$ & $3,311.0$ \\
\hline Registered capital & $15,768.1$ & 746.6 & 522.5 & 588.5 & $1,545.3$ & $3,201.6$ \\
\hline Registered capital 2 & $15,226.3$ & 455.1 & 167.6 & 266.3 & $1,321.8$ & $2,913.8$ \\
\hline $\begin{array}{l}\text { Reserve funds, indivisible fund and } \\
\text { other revenue reserves }\end{array}$ & $8,460.5$ & 106.2 & 102.8 & 268.9 & 229.9 & 496.5 \\
\hline Legal reserve / Indivisible fund & $3,898.4$ & 32.5 & 19.0 & 177.2 & 128.3 & 143.9 \\
\hline Statutory and other funds & $4,296.3$ & 9.7 & 53.0 & 77.9 & 90.8 & 119.2 \\
\hline Profit / loss from previous years & $8,590.4$ & -46.3 & 161.3 & 136.5 & $-1,029.5$ & $-1,019.5$ \\
\hline Retained earnings from previous years & $10,195.7$ & 179.1 & 339.5 & 494.9 & 446.0 & $1,951.1$ \\
\hline $\begin{array}{l}\text { Loss of the previous years before } \\
\text { coverage }\end{array}$ & $-2,130.4$ & -311.6 & -148.0 & -464.4 & $-1,182.4$ & $-2,832.6$ \\
\hline Profit / loss of the current financial year & $3,340.1$ & 10.5 & 131.9 & 130.4 & 8.0 & 91.3 \\
\hline Borrowed capital & $22,970.2$ & 227.4 & $1,656.2$ & $3,829.2$ & $6,420.4$ & $9,661.8$ \\
\hline Long-term liabilities & $5,422.9$ & 53.4 & 350.6 & $1,018.3$ & $1,826.7$ & $2,948.5$ \\
\hline Short-term liabilities & $7,765.0$ & 145.8 & $1,064.1$ & $2,124.2$ & $3,396.4$ & $4,708.6$ \\
\hline Trade liabilities (short-term) & $4,286.0$ & 11.4 & 170.3 & 431.7 & $1,029.8$ & $1,667.6$ \\
\hline $\begin{array}{l}\text { Liabilities to partners, members of } \\
\text { assoc. and participants in association } \\
\text { (short-term) }\end{array}$ & 505.7 & 21.3 & 132.5 & 369.4 & 363.1 & 696.6 \\
\hline Liabilities for employees & 339.5 & 4.8 & 18.7 & 21.2 & 23.0 & 42.6 \\
\hline $\begin{array}{l}\text { Liabilities from social security and } \\
\text { health insurance }\end{array}$ & 202.9 & 2.1 & 9.6 & 20.5 & 37.2 & 29.0 \\
\hline State - tax liabilities and subsidies & 184.2 & 6.4 & 22.6 & -24.8 & 79.8 & 65.9 \\
\hline Bank loans and bailouts & $8,785.4$ & 25.2 & 222.5 & 654.5 & $1,194.4$ & $1,992.4$ \\
\hline Bank loans - long-term & $6,478.1$ & 6.4 & 50.6 & 199.3 & 462.7 & 835.0 \\
\hline Bank loans - short-term & $1,756.2$ & 1.1 & 15.7 & 90.8 & 94.7 & 362.7 \\
\hline
\end{tabular}

Source: own

Note: The values in the table are given in thousands CZK.

the case of the entire set, the amount of equity and borrowed capital is significantly higher than CZK 70 million. The highest capitalized cluster in the examined set is cluster $(5,10)$. There is a slight predominance of borrowed capital. Both funding component achieve the amount higher than CZK 12 million, where the equity accounts for $25 \%$. In the remaining clusters, there is predominantly borrowed capital. The only exception is cluster $(1,8)$. An interesting comparison can be seen in Tab. 4, which shows selected items of profit and loss account.
Agriculture as an institutional sector of national economy identifies a certain degree of self-sufficiency and independence of national economy on other economies. The agriculture performance is less sensitive to fluctuations in economic cycle. However, it is still possible to judge the level of economy according to the agriculture performance share of the total GDP. If the absolute value is high and the relative value is low, the economy is evaluated as developed. This means that not only the sales volume but also performance and value added of agriculture companies is considered. 


\begin{tabular}{|c|c|c|c|c|c|c|}
\hline \multicolumn{7}{|c|}{$\begin{array}{l}\text { Mean values of selected items in profit and loss account for examined set } \\
\text { and selected clusters }\end{array}$} \\
\hline Item & In total & $(1,8)$ & $(3,9)$ & $(3,10)$ & $(4,10)$ & $(5,10)$ \\
\hline Revenues from sold goods & $4,425.9$ & 326.6 & $2,216.0$ & $2,951.3$ & $3,440.9$ & $3,627.6$ \\
\hline Expenses on sold goods & $3,705.3$ & 262.8 & $1,738.7$ & $2,158.1$ & $2,840.6$ & $3,221.4$ \\
\hline Margin & 720.3 & 63.8 & 477.3 & 793.3 & 600.3 & 406.2 \\
\hline Outputs & $30,689.3$ & 521.3 & $2,751.2$ & $2,295.8$ & $2,410.1$ & $3,947.8$ \\
\hline $\begin{array}{l}\text { Revenues from sales of own products } \\
\text { and services }\end{array}$ & $28,117.4$ & 237.0 & $1,067.9$ & $1,276.1$ & $1,137.3$ & $2,424.0$ \\
\hline Change in inventory of own products & -247.2 & -3.7 & -12.0 & -10.2 & 26.2 & 109.6 \\
\hline Activation & $1,030.9$ & 0.2 & 13.0 & 26.3 & 2.7 & 23.8 \\
\hline Outputs consumption & $22,306.0$ & 444.3 & $2,318.8$ & $2,380.8$ & $2,704.5$ & $3,624.1$ \\
\hline Material and energy consumption & $13,933.0$ & 67.7 & 341.7 & 640.6 & 818.8 & $1,365.9$ \\
\hline Services & $6,928.7$ & 133.4 & 528.9 & 776.1 & 756.6 & $1,091.6$ \\
\hline Value added & $9,120.2$ & 139.6 & 915.7 & 709.0 & 305.9 & 729.9 \\
\hline Personal expenses & $6,610.3$ & 131.4 & 730.5 & 705.0 & 725.9 & $1,101.0$ \\
\hline Wages and salaries & $4,487.0$ & 45.7 & 253.7 & 298.8 & 300.5 & 600.0 \\
\hline Social security and health expenses & $1,498.3$ & 12.5 & 74.2 & 84.2 & 92.1 & 190.7 \\
\hline Social expenses & 124.7 & 1.2 & 5.0 & 4.3 & 5.3 & 11.2 \\
\hline Taxes and fees & 256.8 & 5.6 & 14.3 & 22.1 & 32.7 & 49.0 \\
\hline $\begin{array}{l}\text { Intangible and tangible fixed assets } \\
\text { depreciation }\end{array}$ & $3,494.2$ & 37.1 & 176.3 & 294.8 & 420.3 & 667.7 \\
\hline Operating result & $4,330.0$ & 11.2 & 200.0 & 207.8 & 22.0 & 219.8 \\
\hline Economic result & -249.9 & 5.5 & -28.3 & -47.6 & 22.7 & -66.6 \\
\hline Income tax on ordinary activities & 774.4 & 12.2 & 47.9 & 44.3 & 50.3 & 54.4 \\
\hline Economic result of ordinary activities & $3,299.8$ & 5.0 & 125.0 & 115.9 & -5.4 & 98.8 \\
\hline $\begin{array}{l}\text { Economic result for accounting period } \\
(+/-)\end{array}$ & $3,332.4$ & 220.1 & 174.7 & 438.7 & 347.6 & 389.1 \\
\hline Economic result before tax $(+/-)$ & $4,110.0$ & 292.4 & 252.6 & 560.2 & 472.9 & 523.5 \\
\hline
\end{tabular}

Source: own

Note: The values in the table are given in thousands CZK.

The higher the revenues, the better the national economy performs. If even the value added is high, it indicates a significant growth of the entire national economy.

Due to the extent of the contribution, it is possible to pay attention to selected items of profit and loss account only. Fig. 7 compares the mean performance values in agricultural sector.

An average agriculture company performance is higher than CZK 30 million. From the examined cluster, the highest value is achieved by cluster $(5,10)$. Its mean value is almost CZK 4 million. The most represented cluster $(1,8)$ generates an average profit of CZK 0.5 million.

Fig. 8 shows a comparison of economic results achieved. More specifically, it deals with an operating profit, economic result before tax and economic result per accounting period.

For a company, the most important profit category is operating results. This is due to the fact that it represents the results of company activities, or the activity the company was established for. The highest value of operating result and economic result before tax is achieved by the agriculture companies as a whole. The mean values of these two profit 


\section{Fig. 7: Mean performance values for agriculture and for selected clusters}

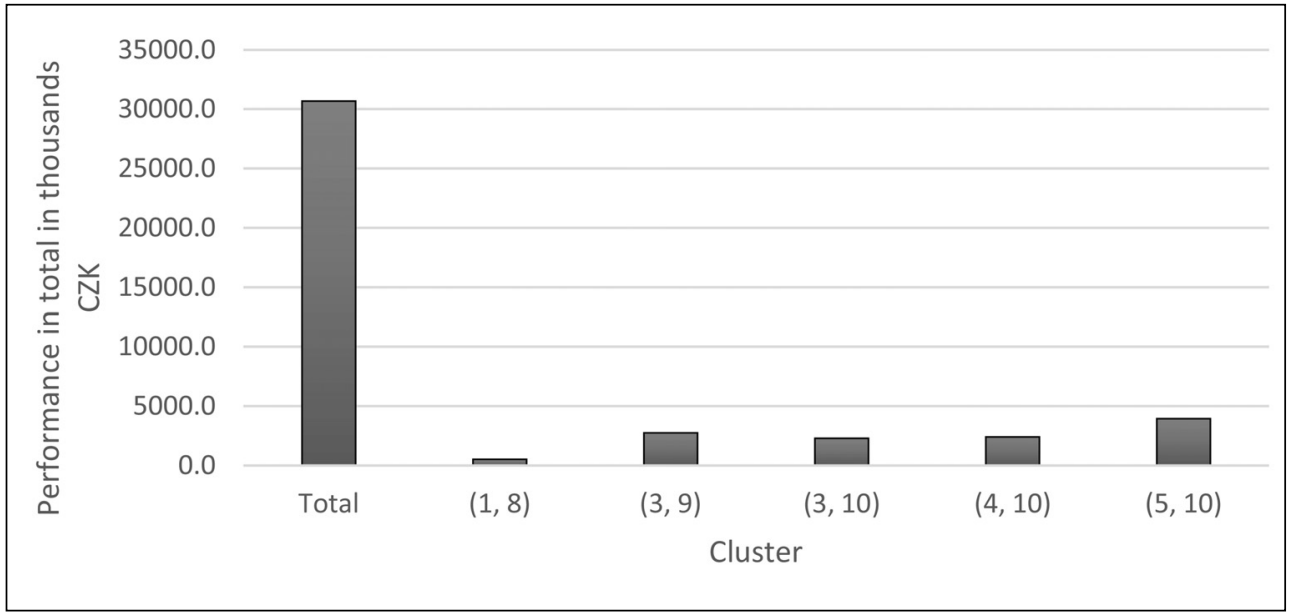

Source: own

\section{Fig. 8: Mean values of economic result for agriculture sector and for selected clusters}

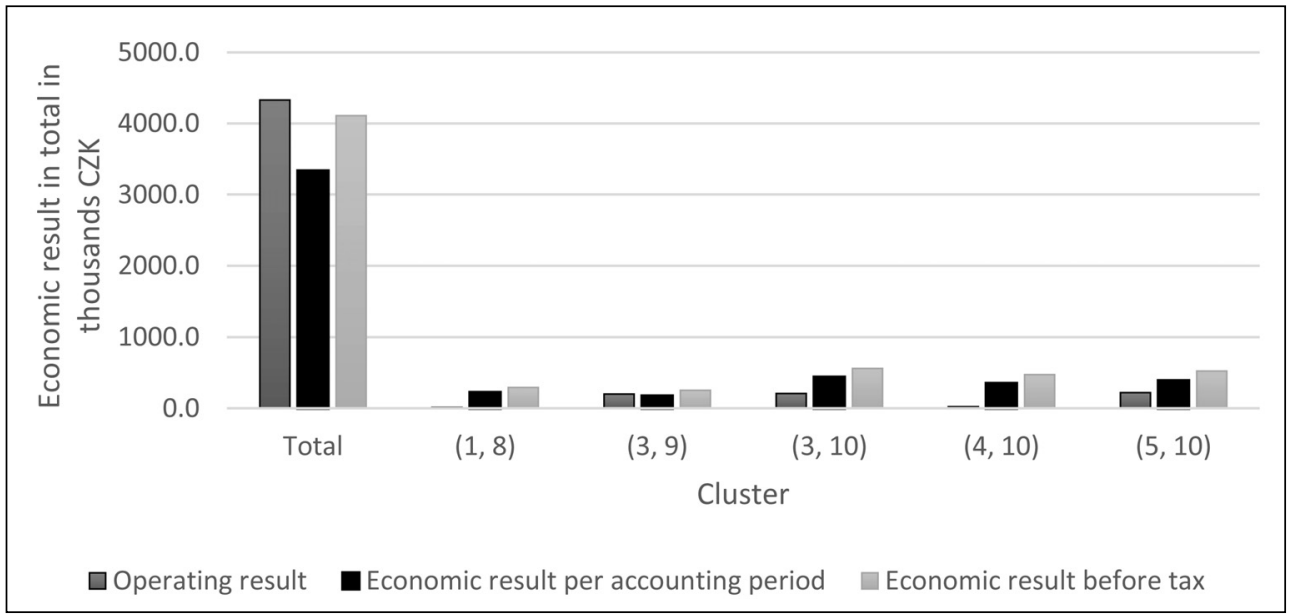

Source: own

categories exceed CZK 4 million; the economic result per accounting period is approx. CZK 3.3 million. Clusters $(3,9),(3,10)$ and $(5,10)$ achieve the economic result at the amount equal to or higher than CZK 0.2 million and more.

So far it could have been assumed that the subjects of comparison were companies of different size, which increased their clustering. Therefore, the results could be distorted. For this reason, the following comparison will be relative, i.e. performed using indicators (ratios) that enable to reduce the differences in the sizes of the companies in the individual clusters. Tab. 5 shows calculated ratios for agriculture sector and for selected clusters. 


\section{Business Administration and Management}

Tab. 5: Selected ratios of mean values for examined set and for selected clusters

\begin{tabular}{l|c|c|c|c|c|c}
\multicolumn{1}{c|}{ Item } & In total & $\mathbf{( 1 . 8 )}$ & $\mathbf{( 3 . 9 )}$ & $\mathbf{( 3 . 1 0 )}$ & $\mathbf{( 4 . ~ 1 0 )}$ & $\mathbf{( 5 . ~ 1 0 )}$ \\
\hline Return on Equity & $6.51 \%$ & $20.72 \%$ & $14.40 \%$ & $30.89 \%$ & $26.04 \%$ & $11.75 \%$ \\
\hline Return on Assets & $4.48 \%$ & $16.97 \%$ & $5.99 \%$ & $8.31 \%$ & $4.47 \%$ & $2.97 \%$ \\
\hline Quick Ratio & 0.75 & 2.20 & 0.68 & 0.36 & 0.21 & 0.22 \\
\hline Current Ratio & 1.81 & 3.57 & 1.34 & 0.90 & 0.66 & 0.72 \\
\hline Total Ratio & 3.04 & 4.04 & 1.60 & 1.20 & 0.89 & 1.05 \\
\hline Debt Ratio & 0.31 & 0.18 & 0.57 & 0.72 & 0.82 & 0.74 \\
\hline
\end{tabular}

Source: own

\section{Fig. 9: ROA and ROE mean values for agriculture sector and for selected clusters}

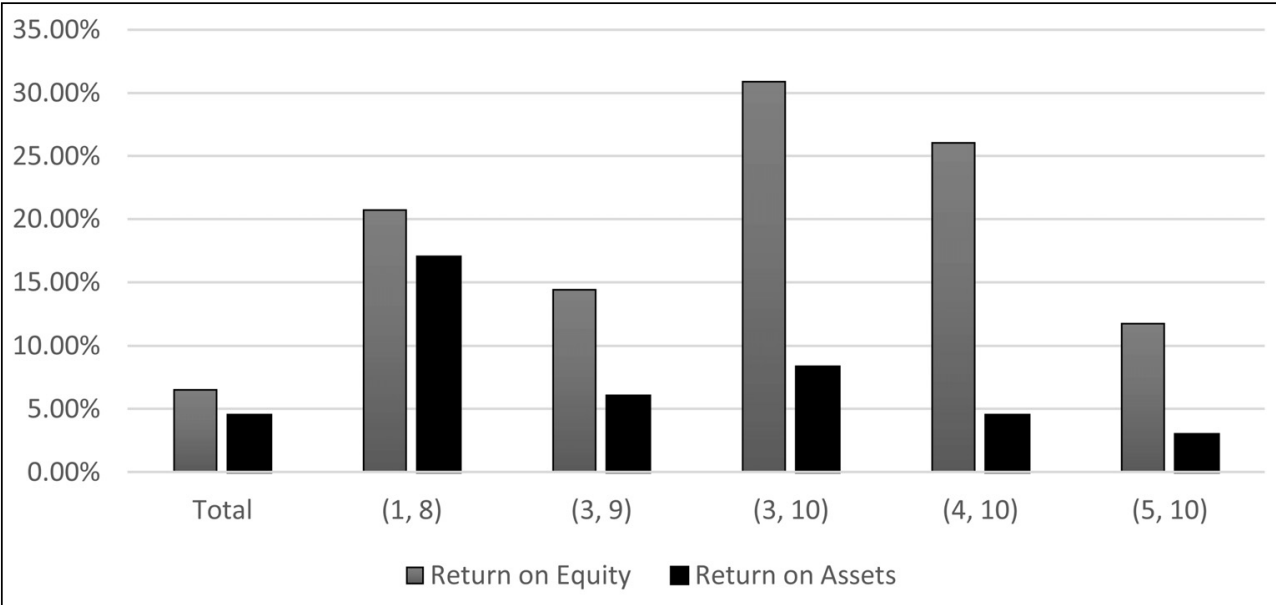

Source: own

The values of return ratios are given in Fig. 9.

Fig. 9 shows that the best results are achieved by cluster $(3,10)$, in particular in terms of ROE. The following positions are occupied by clusters $(4,10),(1,8)$ and $(3,9)$. All of the clusters examined achieved the aboveaverage results, except for the $(5,10)$ cluster ROA. However, it can be stated that agriculture was successful in 2016. If disregarding the investment risk rate, for investors it was a very attractive possibility of investing free capital. Compared to the interest rates of Czech banks, the interest rate was high.

Fig. 10 shows the liquidity values for agriculture companies as a whole and for examined clusters.
Fig. 10 shows that the lowest values are for the cluster $(4,10)$. Generally, it holds true that smaller companies achieve higher liquidity values and large companies hold a lower level of liquidity. This is naturally associated with the fact that large companies are less likely to be in insolvency than small companies. This is confirmed by the values obtained for agriculture and for the cluster $(1,8)$. Conversely, the companies of clusters $(4,10),(5,10)$ and $(3$, $10)$ seem to be able to accept higher risk of not being able to pay their liabilities.

\section{Conclusions}

The objective of the contribution was to analyse the agriculture companies in the Czech 


\section{Fig. 10: Mean liquidity ratio values for agriculture sector and for selected clusters}

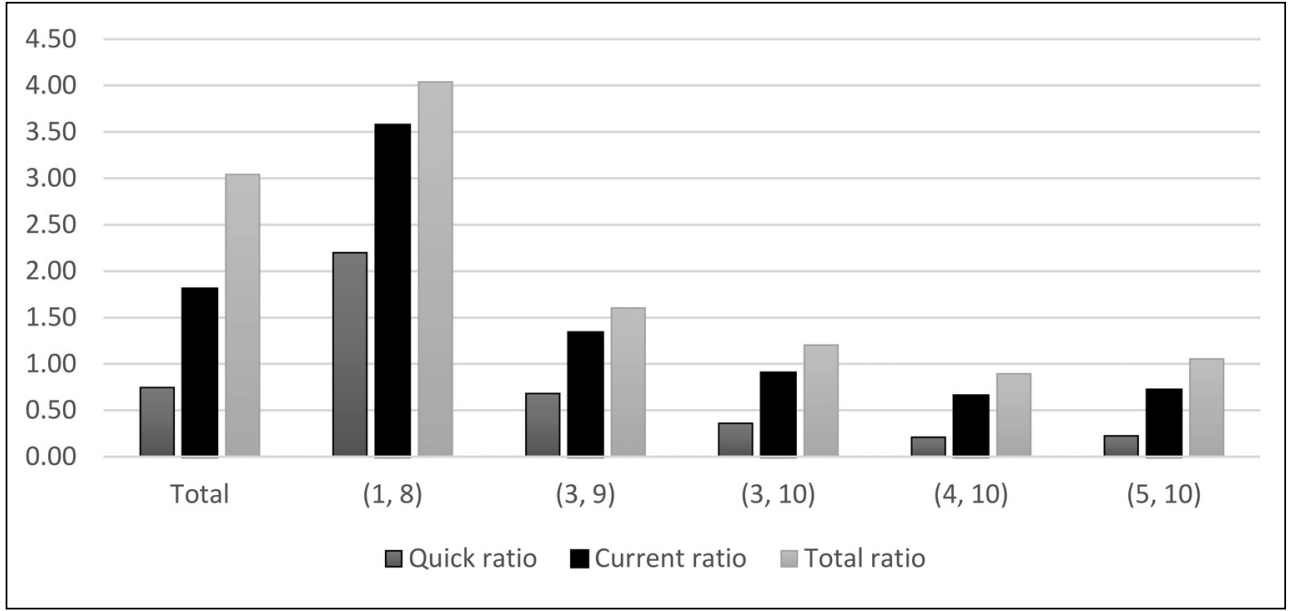

Source: own

Republic using Kohonen networks and to estimate their development. In addition to the considerable benefits, the Kohonen networks also have disadvantages that we need to be careful about. The disadvantages of Kohonen networks are the inability to measure the "performance" of the map and the need to manually check the accuracy of the created clusters. Another disadvantage that applies to most neural networks in general is the "slowness" of learning.

The objective of the contribution was achieved. A cluster analysis was performed. From the clusters, those with highest frequency counts were selected. Subsequently, absolute values of selected items of financial statements were analysed. A typical representative of the cluster was determined by means of calculating arithmetic average of the cluster examined.

It can be stated that the agriculture companies show very favorable values optimal assets level, acceptable financing structure and adequate economic result. It can be even stated that the indicators show aboveaverage values compared to other investment options.

The results of individual clusters can be summarized as follows:

1. The companies with highest frequency counts in clusters account for $45 \%$ of companies active in agriculture sector.
2. The examined clusters showed lower, sometimes significantly lower, values of selected financial statements items (balance sheet, fixed assets, economic result, etc.).

3. It follows that the examined $80 \%$ of companies do not generate $80 \%$ of outputs of agriculture sector.

4. It follows that the remaining $55 \%$ are significantly more important for the agriculture sector outputs than that one corresponding to $55 \%$.

It can be concluded that the remaining $20 \%$ shall be examined thoroughly examined. It shall also be identified which companies (or clusters) have positive impact on the outputs of the entire agriculture sector. This would enable to predict the future development of the whole institutional sector of national economy. We can find out by other statistical methods, and at the same time, we can use artificial intelligence again, for example, to determine the value-generators of the enterprises. This will determine which items in the financial statements of the selected companies have the greatest impact on the value of these companies.

\section{References}

Altun, H., Bilgil, A., \& Fidan, B. C. (2007). Treatment of multi-dimensional data to enhance 
neural network estimators in regression problems. Expert Systems with Applications, 32(2), 599605. https://doi.org/10.1016/j.eswa.2006.01.054.

Andekina, R., \& Rakhmetova, R. (2013). Financial Analysis and Diagnostics of the Company. Procedia Economics and Finance, 5 , 50-57. https://doi.org/10.1016/S22125671(13)00008-7.

Arrow, K. J., Forsythe, R., Gorham, M., et al. (2008). Economics - The Promise of Prediction Markets. Science, 320(5878), 877-878. https://doi.org/10.1126/science.1157679.

Čechura, L. (2012). Technical efficiency and total factor productivity in Czech agriculture. Agricultural Economics, 58(4), 147-156. https://doi.org/10.17221/56/2011-AGRICECON.

Dokic, M., Jovanovic, V., \& Vujanic, I. (2017). Using the TFP index to measure changes in agricultural productivity in the EU. Casopis za Ekonomiju i Trzisne Komunikacije, 7(2), 283-297.

Han, X., \& Wang, L. (2008). Stock Company Comprehensive Assessment Model Based on Kohonen Network. In Y. Du, M. Zhao (Ed.), Second International Conference on Genetic and Evolutionary Computing (185-188). China: IEEE. https://doi.org/10.1109/WGEC.2008.97.

Hedtrich, F., Loy, J. P., \& Mueller, R. A. E. (2012). Prediction Markets - a promising tool for the agricultural sector? Berichte Uber Landwirtschaft, 90(2), 201-223.

Hossain, M. S., Chao, O. Z., Ismail, Z., Noroozi, S., \& Khoo, S. Y. (2017). Artificial neural networks for vibration based inverse parametric identifications: A review. Applied Soft Computing, 52, 203-219. https://dx.doi. org/10.1016/j.asoc.2016.12.014.

Karas, M., \& Režňáková, M. (2017). The stability of bankruptcy predictors in the construction and manufacturing industries at various times before bankruptcy. $E \& M$ Economics and Management, 20(2), 116-133. https://dx.doi.org/10.15240/tul/001/2017-2-009.

Klepáč, V., \& Hampel, D. (2018). Predicting bankruptcy of manufacturing companies in EU. E\&M Economics and Management, 21(1), 159-174. https://dx.doi.org/10.15240/tul/001/2018-1-011.
Klieštik, T., Mišánková, M., Valášková, K., \& Švábová, L. (2018). Bankruptcy prevention: New effort to reflect on legal and social changes. Science and Engineering Ethics, 24(2), 791-803. https://doi.org/10.1007/s11948017-9912-4.

Klieštik, T., Vrbka, J., \& Rowland, Z. (2018). Bankruptcy prediction in Visegrad group countries using multiple discriminant analysis. Equilibrium-Quarterly Journal of Economics and Economic Policy, 13(3), 569-593. https://doi.org/10.24136/eq.2018.028.

Konečný, V., Trenz, O., \& Svobodová, E. (2010). Classification of companies with the assistance of self-learning neural networks. Agricultural Economics, 56(2), 51-58.

$\mathrm{Li}, \mathrm{Ch}$. (2018). Evaluation of the financial and economic development of the European Union member states on basis of multiple indicators changed to multiple objectives. E\&M Economics and Management, 21(4), 19-32. https://dx.doi.org/10.15240/tul/001/2018-4-002.

Remeikiene, R., Rozsa, Z., Gaspareniene, L., \& Pěnčík, J. (2018). Assessment of the impact of the international trade in agricultural products on the EU economic growth. E\&M Economics and Management, 21(4), 33-47. https://dx.doi.org/10.15240/tul/001/2018-4-003.

Rivera-Ferre, M. G. (2008). The future of agriculture. Agricultural knowledge for economically, socially and environmentally sustainable development. EMBO Reports, 9(11), 1061-1066. https://doi.org/10.1038/ embor.2008.196.

Rowland, Z., \& Vrbka, J. (2016). Using artificial neural networks for prediction of key indicators of a company in global world. Globalization and its Socio-Economic Consequences, 16th International Scientific Conference Proceedings. 1896-1903. Slovakia: Žilina.

Santin, D. (2008). On the approximation of production functions: A comparison of artificial neuralnetworksfrontiersandefficiencytechniques. Applied Economics Letters, 15(8), 597-600. https://doi.org/10.1080/13504850600721973. 
Valášková, K., Klieštik, T., Švábová, L., \& Adamko, P. (2018). Financial risk measurement and prediction modelling for sustainable development of business entities using regression analysis. Sustainability, 10(7), 2144. https://doi.org/10.3390/su10072144.

Vochozka, M., Rowland, Z., \& Vrbka, J. (2016). Financial analysis of an average transport company in the Czech Republic. Nase More, 63(3), 227-236. https://doi.org/10.17818/ $\mathrm{NM} / 2016 / \mathrm{SI} 28$.

Vochozka, M., \& Machová, V. (2018). Determination of value drivers for transport companies in the Czech Republic. Nase More, 65(4), 197-201. https://doi.org/10.17818/ NM/2018/4SI.6.

Vochozka, M. (2017). Formation of complex company evaluation method through neural networks based on the example of construction companies' collection. AD ALTA-Journal of Interdisciplinary Research, 7(2), 232-239.
Ing. Vojtěch Stehel, MBA, PhD. Institute of Technology and Business in České Budějovice Faculty of Technology Czech Republic stehel@mail.vstecb.cz

Ing. Jakub Horák Institute of Technology and Business in České Budějovice

School of Expertness and Valuation

Czech Republic horakl@mail.vstecb.cz

prof. Ing. Marek Vochozka, MBA, Ph.D. Institute of Technology and Business in České Budějovice School of Expertness and Valuation Czech Republic vochozka@mail.vstecb.cz 


\title{
Abstract
}

\section{PREDICTION OF INSTITUTIONAL SECTOR DEVELOPMENT AND ANALYSIS OF ENTERPRISES ACTIVE IN AGRICULTURE}

\author{
Vojtěch Stehel, Jakub Horák, Marek Vochozka
}

The overall EU agricultural productivity growth has slowed down in recent years and has lagged behind leading global competitors, which is mainly due to decreasing number of employees in agriculture. Technical inefficiency is then an important phenomenon of the Czech agriculture and its individual sectors. Agriculture development should be established on scientific bases. One of the basic principles of sustainable agriculture is therefore forecasting its future development. In recent years, several agricultural economists have been engaged in comparing forecasts with various other methods and their conclusions generally correspond to commonly accepted beliefs. At present, artificial intelligence can be definitely recognized as a useful tool for business analyses and forecasting. The objective of the contribution is an analysis of companies active in agriculture of the Czech Republic using Kohonen network and the subsequent prediction of their development. A data set is created, which includes complete data from financial statements of 4,201 companies active in agriculture of the Czech Republic in 2016. The set of companies is generated from the Bisnode Albertina database. The data set is subsequently subjected to cluster analysis using Kohonen network. For cluster analysis, Dell's Statistica software, version 12 is used. The set is divided into three parts: training data set, testing data set, validation data set. Topological length and width of Kohonen network are set at 10. The number of iterations is set at 10000 . Subsequently, the individual clusters are subjected to analysis of absolute and selected indicators (or more precisely, their mean values - arithmetic average) and the results are interpreted. It can be stated that the agriculture companies show very favorable values - optimal assets level, acceptable financing structure and adequate economic result. It can be even stated that the indicators show above-average values compared to other investment options.

Keywords: Agriculture enterprises, institutional sector development, prediction, artificial neural networks, value of the business.

JEL Classification: C45, 013.

DOI: 10.15240/tul/001/2019-4-007. 